\title{
Impact of the landslide for a Relationship between Rainfall Condition and Land Cover in North Vietnam
}

\author{
Thuy Thi Thanh Le and Seiki Kawagoe \\ Faculty of Symbiotic Systems Science, Fukushima University, Kanayagawa 1, Fukushima City, 960-1296 Fukushima, Japan
}

\begin{abstract}
This paper aims to evaluate the probability of landslide hazards using a physical model (TRIGRS: Transient Rainfall Infiltration and Grid-Based Region Slope-Stability) for a regional scale considering the variations of a triggering rainfall condition and land-cover under the climate change. There are certain uncertainties raising from the soil properties and soil depth determination, assumption of groundwater, as well as the same root cohesion for all tree cover in the forest-related region. However, the application of TRIGRS model in a regional scale would provide important references for the distribution of landslide prone area regarding scenarios about changes of weather condition and land cover situation. It thus would support local authorities in obtaining more adequate land planning strategies in a river basin to mitigate potential hazard from the slope failure issue.
\end{abstract}

Key words: Climate change risk, extreme precipitation event, land use change, scenario, the factor of safety (Fs).

\section{Introduction}

Recently, extreme precipitation events have been occurring in Vietnam with higher intensities and more frequencies; heavy rainstorms have led to water-related disasters such as floods, debris flows, and landslides. North-eastern Vietnam is considered as one of the landslide-prone areas, in which heavy rainfall, hydro-geological features, as well as human interferences in land-cover and natural slope condition are major contributors to the landfall occurrences. To support the economic development in the mountainous region in the Northeast, many arteries have been constructed and developed across the area for the ease of transportation among residential zones. Mining and deforestations also converted forest land to bared land on hilly sides. The expansion of poor-planning activities has resulted in high risk of slope failures especially under triggering events including prolonged-extreme rainfall; such failure has also borne catastrophic consequences to the society. For example,

Corresponding author: Seiki Kawagoe, Ph.D., Impact of the Landslide for a Relationship between Rainfall Condition and Land Cover in North Vietnam, research fields: sediment disaster, hydrology. downpour in 29-30 May 2013 in Bac Kan (Fig. 1) province caused many sliding points across this province; the road 258 from the Bac Kan city to $\mathrm{Ba} \mathrm{Be}$ district was closed totally within $40 \mathrm{~km}$ in one month and partial sections of this road were still under rehabilitation after 2 months.

With regards to the landslide susceptibility approach, there are two widely used methods: the qualitative method, and the quantitative method [1-3]. The qualitative method includes the inventory approach and heuristic approach; is often applied for a regional scale. The statistical method is often based on ground survey in a relationship with historical information to evaluate major factors of sliding occurrences; however, it does not predict the landslide susceptible areas. The heuristic method needs long-term data of historical landslide and its causative factors; it depends strongly on the experiences and knowledge of the scientists in assessing the degree of landslide hazards. In addition, the statistical and the deterministic approaches are 2 major applications of the quantitative method. In this technique, mathematical models area utilized to evaluate the probability of slope failure in order to identify landslide-prone areas. The statistical method 


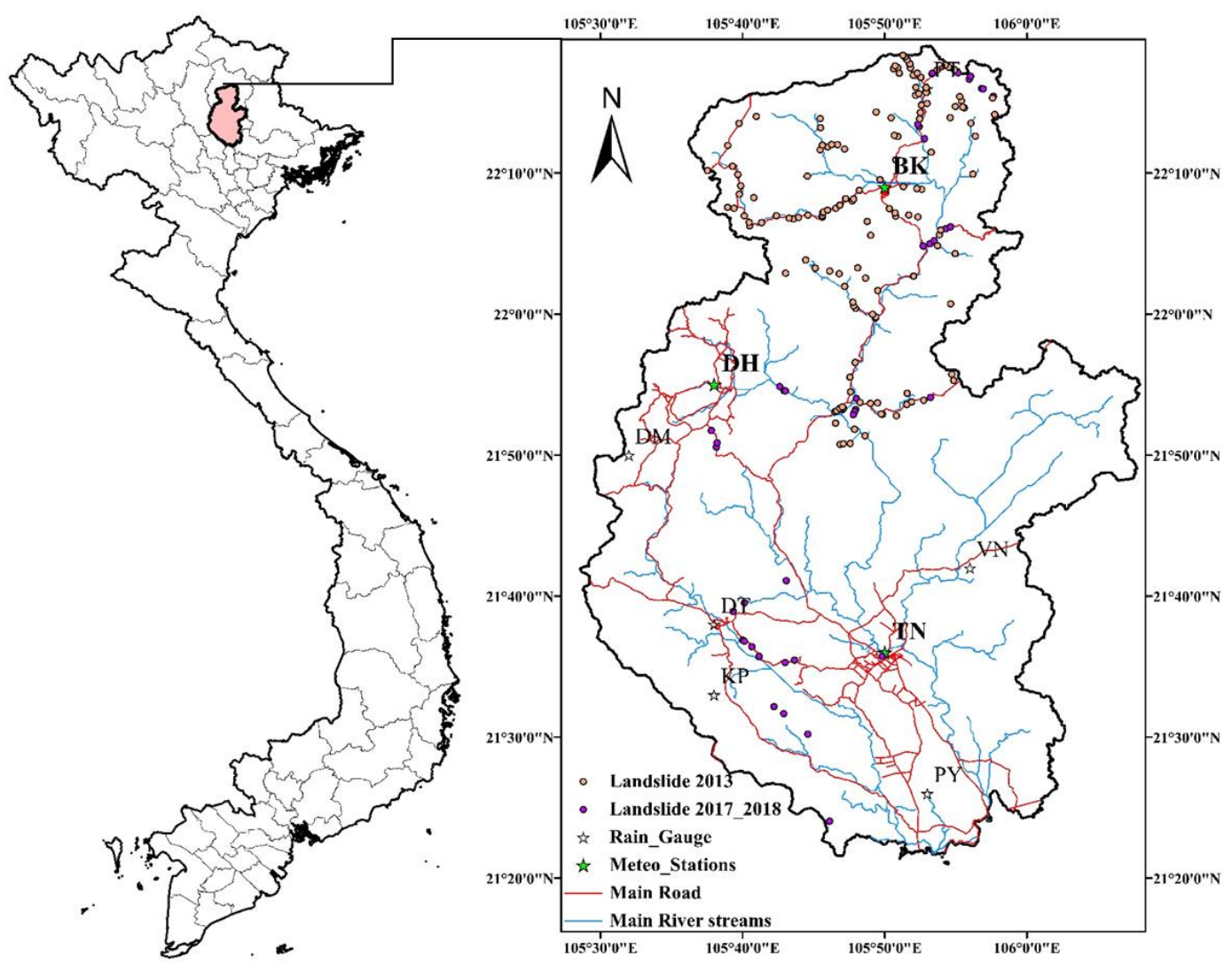

Fig. 1 Cau Basin in Vietnam.

bases on the relationship between historical landfall and its instability parameters; however the requirements of large amount of data therefore lead to main application of this method in a medium scale. The deterministic approach utilizes physical models to estimate the factor of safety and can be applied for detailed research at a large scale [4]. In this method, the geology condition is often assumed to be homogenous; difficulties in data processing especially regard to large spatial dataset often hinder the application of the deterministic method in a regional scale [2].

Recent studies in the North region usually apply the statistical method to evaluate the slope-stability condition for a regional scale; while the main approach for a small region is often belonged to the deterministic method. For instance, phase 1 of the national project 2012-2020 has released inventory maps for 14 provinces in the North area (Fig. 1) using the transect-walk along major transportation routes to record historical landslides, which were mainly related to failures on man-made slopes in populated regions. In fact, changes in natural slope conditions in relation to the higher and more frequencies of extreme precipitation as a result of climate change could bring about high risk of landfalls in this agricultural area.

This paper aims to evaluate the probability of landslide hazards using a physical model for a regional scale considering the variations of a triggering rainfall condition and land-cover under the climate change.

\section{Study Area}

This paper focuses on the Cau river basin in Northeast Vietnam. This basin covers the southern region of Bac Kan province and almost all area of Thai Nguyen province. The rainy season often lasts from May to early October with the maximum daily precipitation of about $208-496 \mathrm{~mm}$; the annual rainfall varies from $1,360 \mathrm{~mm}$ to $2,572 \mathrm{~mm}$. This study area is covered by both mountainous terrain in the North and Southwest, as well as hilly sites in the South and 
Southeast regions; almost all area has the elevation of less than 300 meter (Fig. 2). Regarding to the Geological and Mineral Resources Map of Vietnam at the scale of 1:200,000, there are 19 formations in this basin (Fig. 3). The Phu Ngu and Mia Le formations dominate in Northern part; the southern region in Thai Nguyen province is mainly covered by $\mathrm{Ha}$ Coi formation. There are seven groups in the lithology condition in the catchment as described in Fig. 3; they are: (1) Quaternary deposits; (2) Sedimentary aluminosilicate rocks and sedimentary quartz rocks; (3) Sedimentary carbonate rocks; (4) Mafic-ultramafic magma rocks; (5) Acid-neutral magmatic rocks; (6) Metamorphic rocks with rich aluminosilicate components and (7) Metamorphic rocks with rich quartz components. Moreover, based on the 10-year data (2001-2010), the U.S Geological Survey (USGS) classified the land-cover in this area into 10 categories as described in Fig. 4: (0) Water; (2) Evergreen broadleaf forest; (5) Mixed forests; (6) Closed shrub lands; (8) Open shrub lands; (9) Savannas; (11)
Permanent wetland; (12) Croplands; (13) Urban and built-up; and (14) Cropland/natural vegetation mosaic [5]. Moreover, according to the research of the Japan Aerospace Exploration Agency (JAXA), nine sub-classes of land-use cover are: (1) Water; (2) Urban and built-up; (3) Rice; (4) Other crops; (5) Grasslands; (6) Orchards; (7) Barren; (8) Forest; and (9) Mangrove [6]. In this rural region, high rise in the population size has borne high pressure on the development of infrastructure and residential zones. Poor land-management activities in this area also resulted in a great change in the forest cover. According to the general statistic data, there was 1,857 ha of forest being cut down during the period from 2006-2016; while only 326 ha of forest was planted. Whilst the official statistic data of deforestation in Vietnam was often smaller than the real situation; the aforementioned data revealed the fact that the vegetation cover in this basin decreased significantly during 10 years. The change in land-cover was also seen from the differences among database as illustrated in Fig. 4.

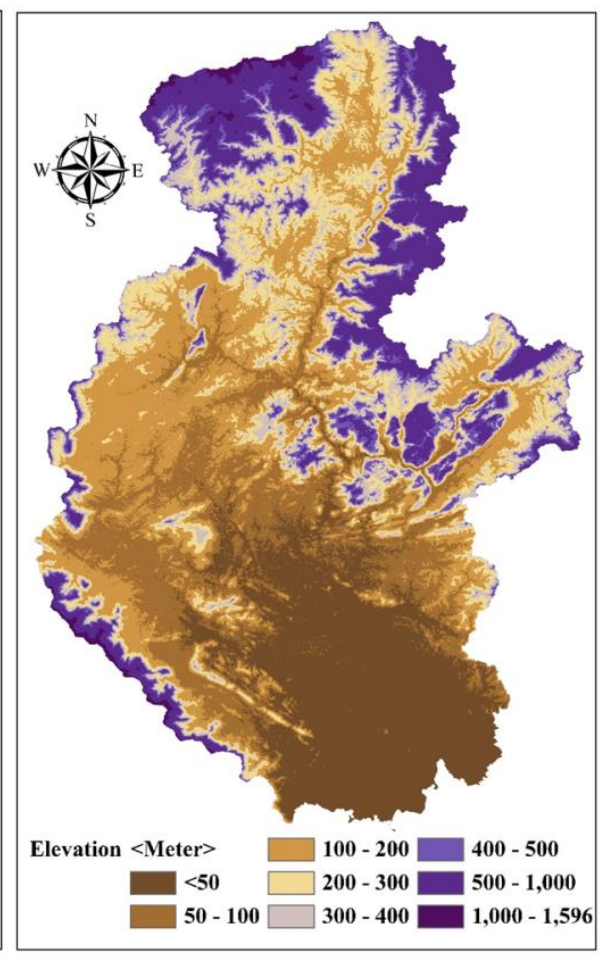

(b) Elevation

Fig. 2 Geomorphological feature map in Cau Basin. 


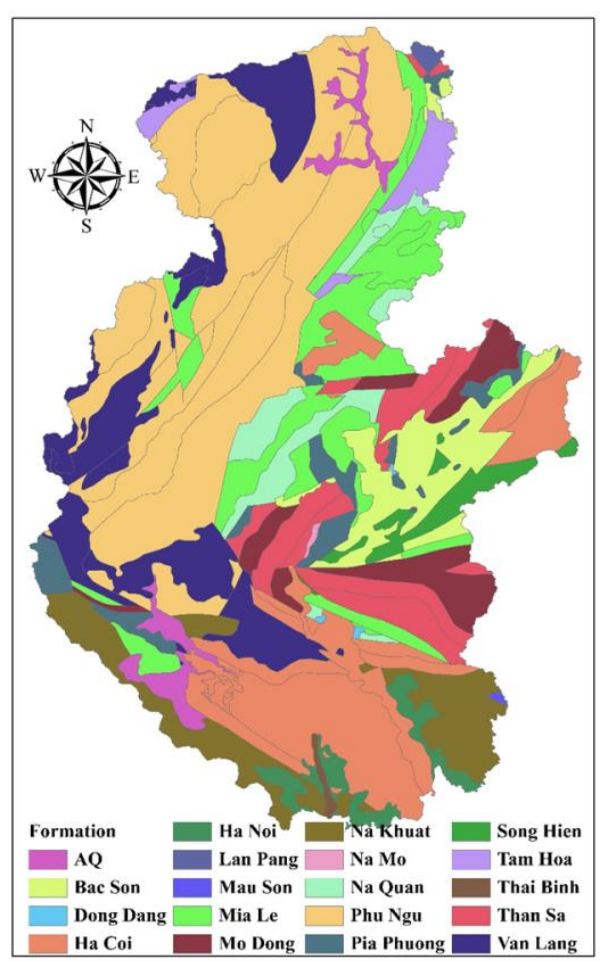

(a) Formation map

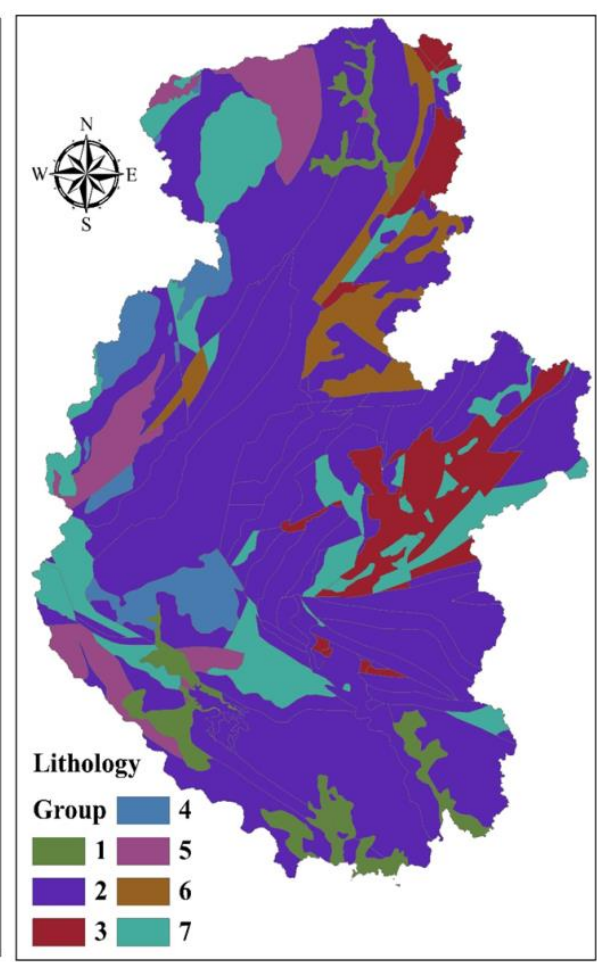

(b) Lithology map

Fig. 3 Geological condition map in Cau Basin.

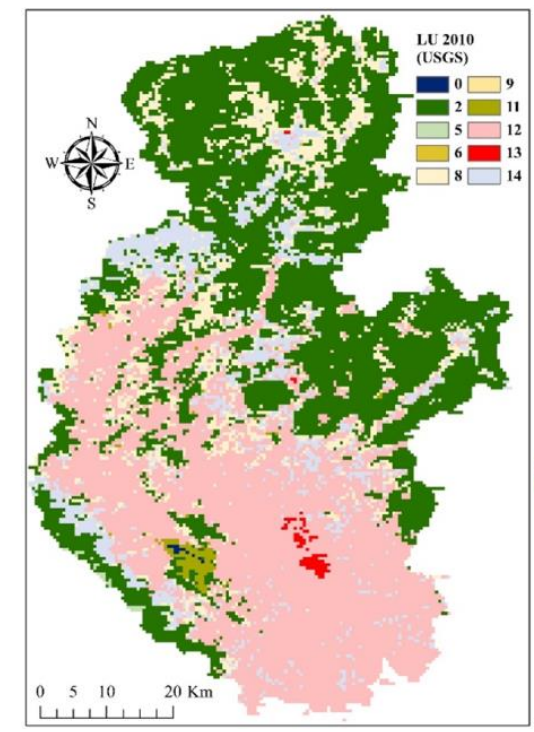

(a) Land use 2010 (USGS)

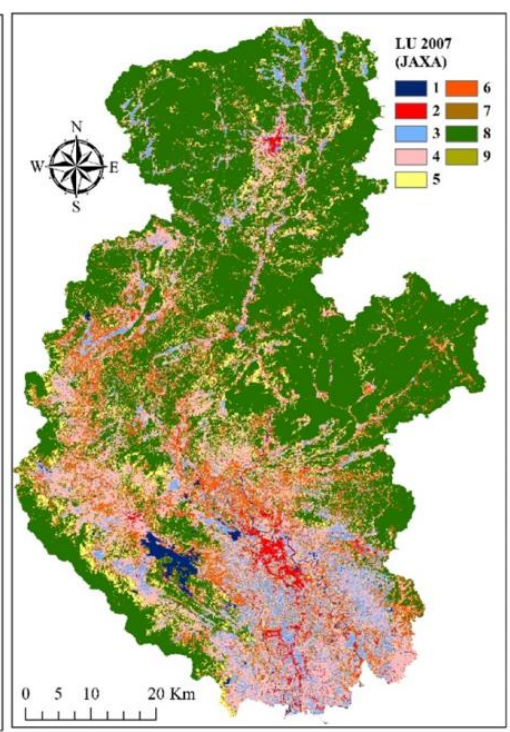

(b) Land use 2007 (JAXA)

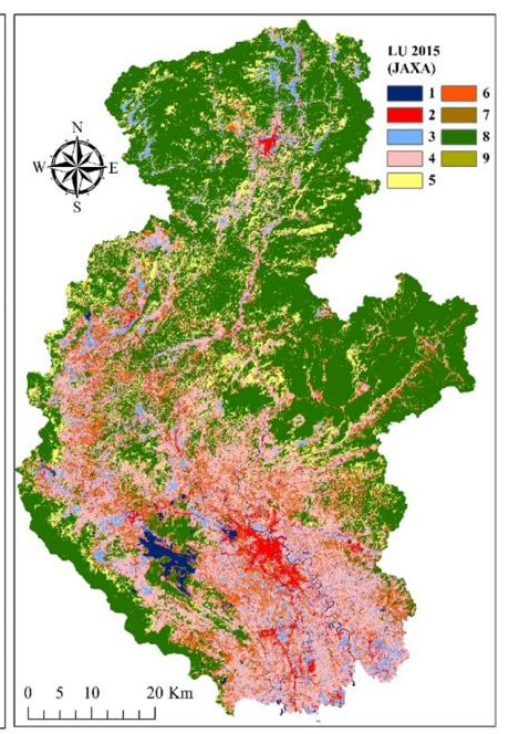

(c) Land use 2015 (JAXA)

Fig. 4 Land use map in Cau Basin.

\section{Methodology}

In this paper, we apply the Transient Rainfall Infiltration and Grid-Based Region Slope-Stability (TRIGRS) model to evaluate the landslide hazard in the $\mathrm{Cau}$ basin. The computation was assessed on a cell-by-cell basis to determine the value of factor of safety (Fs), and pore-water pressure [7]. This model is often applied for evaluating the rainfall-induced landslide because it calculates changes in the transient pore pressure and the $F s$ as a result of the rain infiltration. The factor of safety (Fs) below the ground 
surface was derived from the balance between the downslope components of the gravitational driving stress and the resisting stress for saturated soils as illustrated in Eq. (1) [7, 8]:

$$
\operatorname{Fs}(Z, t)=\frac{\tan \varphi}{\tan \delta}+\frac{\mathrm{c}-\Psi(Z, t) \gamma_{\mathrm{w}} \tan \varphi}{\gamma_{\mathrm{s}} Z \sin \delta \cos \delta}
$$

where $\varphi$ represents the soil friction angle $\left(^{\circ}\right) ; \delta$ is the slope angle $\left({ }^{\circ}\right) ; c$ presents the cohesion $\left(\mathrm{kN} / \mathrm{m}^{2}\right) ; \gamma_{s}$ and $\gamma_{w}$ refer to the unit weight of soil and the unit weight of water, respectively $\left(\mathrm{kN} / \mathrm{m}^{3}\right) ; Z$ is the depth below the ground surface (m); $t$ indicates the time (second); $\Psi$ is the ground water pressure head as a function of depth $Z$ and time $t(\mathrm{~m})$.

In this study, we applied a scenario-based approach to assess the landslide hazard under the impact of extreme rain events. Input parameters for this approach include rainfall amount and duration, soil physical parameters, hydro-geology condition, and terrain features. Above information was discretized and assigned in each cell to simulate the infiltration through the unsaturated zone of the soil layer. To assign the soil depth information in the model, we determine this parameter using the empirical relationship between topography attributes and soil thickness as shown in the Saulnier method [9]. Eq. (2) indicates the decreasing linear function between terrain slope and soil depth:

$$
Z_{\mathrm{i}}=Z_{\text {max }}\left[1-\frac{\tan \delta_{\mathrm{i}}-\tan \delta_{\text {min }}}{\tan \delta_{\text {max }}-\tan \delta_{\text {min }}}\left(1-\frac{Z_{\text {min }}}{Z_{\text {max }}}\right)\right]
$$

where $\delta_{\min }$ and $\delta_{\max }$ refer to the minimal and maximal values of slope angle(degree), $Z_{\min }$ and $Z_{\max }$ represent the minimum and maximum values of effective soil depths, respectively; $Z_{i}$ and $\delta_{i}$ are the soil depth and slope angle at the calculated cell $i$.

This article also assesses the additional cohesion component $(\Delta c)$ from the root system that contributes to the shear strength $(s)$ following the Mohr-Coulomb formulation [10] as shown in Eq. (3):

$$
\mathrm{s}=\mathrm{c}+\sigma_{\mathrm{N}} \tan \varphi=\left(\mathrm{c}_{\mathrm{s}}+\Delta \mathrm{c}\right)+\sigma_{\mathrm{N}} \tan \varphi
$$

where $\sigma_{N}$ refers to the normal stress on the shear plane $\left(\mathrm{kN} / \mathrm{m}^{2}\right) ; c_{s}$ represent the soil cohesion $\left(\mathrm{kN} / \mathrm{m}^{2}\right) ; \Delta c$ is the apparent cohesion provided by roots $\left(\mathrm{kN} / \mathrm{m}^{2}\right)$. For simplicity, in this study, the tree-surcharge impacts were ignored; the mechanical impact of tree cover on the shear strength of soil on hilly side with vegetation cover is represented only by the root cohesion $(\Delta c)$.

In this article, we used rainfall record from 1960-2016 to estimate the spatial and temporal distribution of heavy storm event in order to simulate the rain-induced landslide susceptibility regarding different scenarios of precipitation.

The actual rainstorm event was selected based on the recent storm events that resulted in landslides during the period from 2010 to 2016. It is noted that the historical landslide data in North part of this catchment were recorded mainly in 2013 under the government project throughout the landslide inventory map in Bac Kan province. Although this data is mainly associated with the failure on the artificial slopes along the road, the landslide data in 2013 still provided important records for the landfall assessment in this river basin. In this paper, we utilized heavy rainstorm in 2013 to analyze the stability condition of slope sites in this catchment. The spatial distribution of rain was estimated by the Thiessen polygon weighting method. In addition, under the impact of warming climate, heavier precipitation would occur throughout the world. The magnitudes of extreme rain under the rise of the air temperature were computed based on the Probable Maximum Precipitation (PMP) using the moisture maximization method [11, 12]. The spatial distributions of rainstorm in 2013 and PMP regarding two main durations ( 24 hours and 48 hours) are shown in Fig. 5.

The proposed distributions of extreme rain events were estimated based on the analysis from actual 68 heavy storm events in the Northeast region from 1960-2016. The duration of heavy storm lasted from 5 hours at Tuyen Quang station on 1984/6/22 to 53 hours at Bac Kan station on 1990/9/21 (Fig. 6a). The analysis grouped the distribution of a storm event into three main types:

(i) Type 1: peak rainfall locates at the beginning of the storm; 


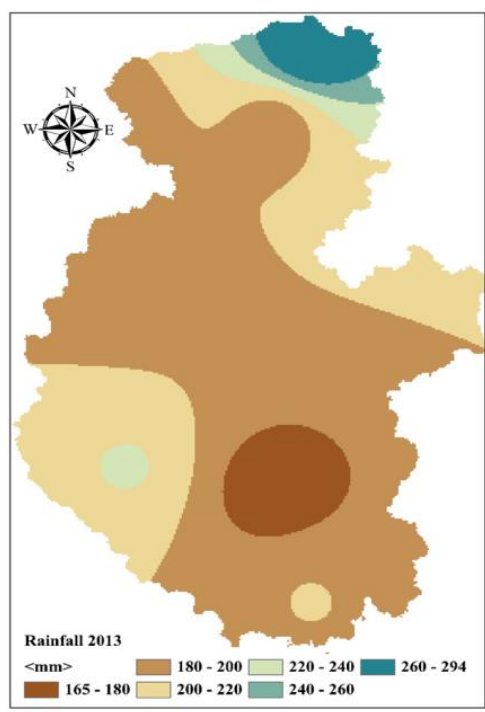

(a) Rainstorm in 2013

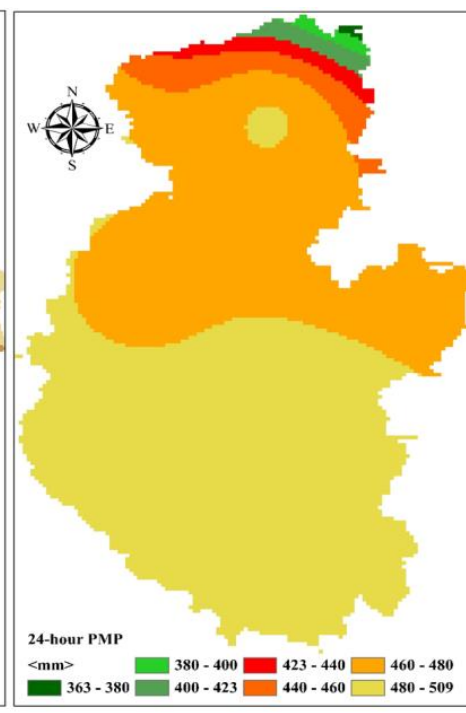

(b) 24-hour PMP condition

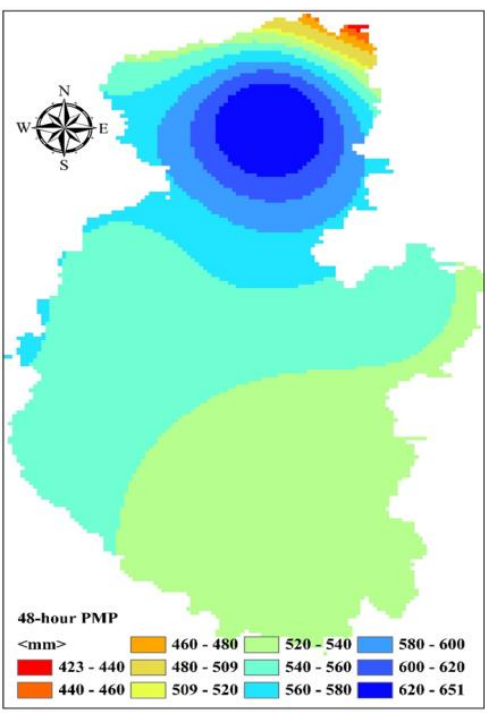

(c) 48-hour PMP condition

Fig. 5 Precipitation condition map in Cau Basin.

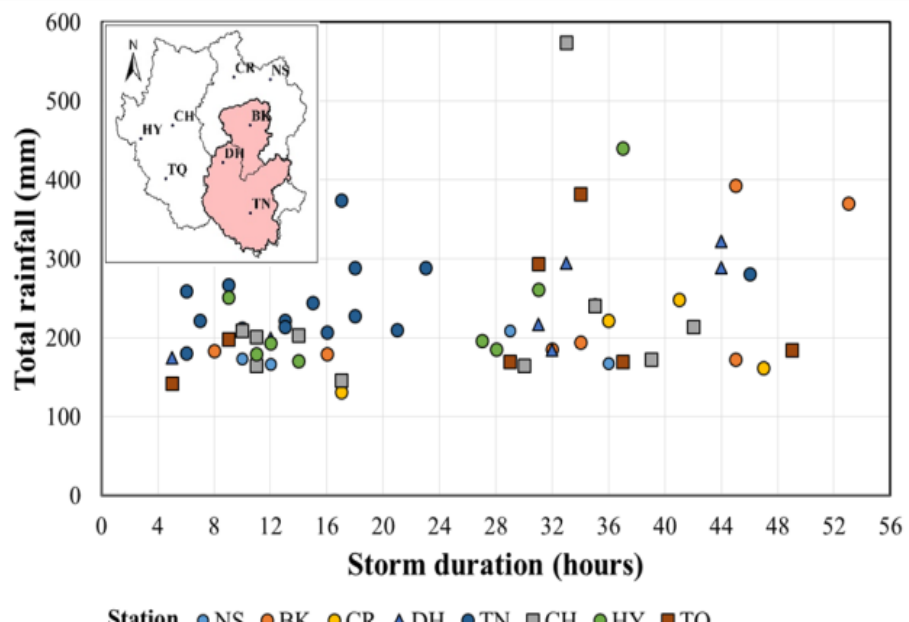

(a) Relationship between total amount of rainfall and storm duration of heavy storm events at six meteorological stations

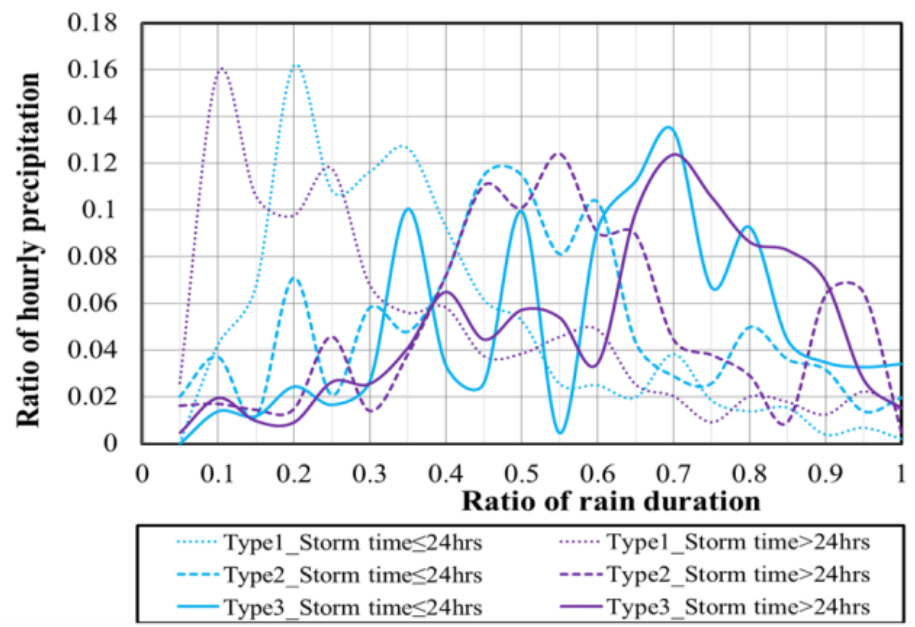

(b) Three main distribution types of heavy rainstorm in the study area

Fig. 6 Actual rainstorm condition. 
(ii) Type 2: peak rain locates at the middle of the storm time; and

(iii) Type 3: peak precipitation appears at the end of the storm (Fig. 6b).

Summarize of extreme precipitation is illustrated in Table 1. Information of soil and hydro-geology in the catchment was gathered from recent studies [13-19]. Samples from the field investigations in 2017 and 2018 in the basin were tested in the geotechnics laboratory at Thuy Loi University (in Vietnam). The average input parameters of soil properties regarding main geology regions are summarized in Table 2.

\section{Results}

\subsection{Scenarios Setup}

In order to set up scenarios in evaluating the slope stability state in the Cau basin, we consider four major components: (a) rainstorm event including rainfall total and duration, (b) rainfall distribution, (c) land cover condition, and (d) soil depth estimation. Options for extreme precipitation include storm event in 2013 as well as the PMP as mentioned in Section 3. Information about the land cover condition was applied from JAXA (2007 \& 2015). With regard to the impact of vegetation cover on the slope stability, the cohesion $c$ equals the sum of the soil cohesion $c_{s}$ and the root cohesion $\Delta c$. Applying the trial-and-error method, the average values of $\Delta c$ ranged from $0.7 \mathrm{kN} / \mathrm{m}^{2}$ for orchards, shrub lands, and savannas land-cover to 1.0 $\mathrm{kN} / \mathrm{m}^{2}$ for forest cover [20-22]. Information of average depth of soil in the study area was obtained from the national reports about geology and lithology in the North region. In this article, we used two options for soil depth determination including (i) case 1: based on the lithology map, the maximum depth of soil ranged from 4 meters on the flat surface to 0.5 meters on the steepest mountain side; (ii) case 2: based on lithology map and geology distribution in the basin, the maximum thickness of soil layer varied from 3 meters on plane surface to 0.5 meters on the steepest hill sides. Detailed information of two cases is displayed in Table 3 and Fig. 7.

The initial groundwater table was assumed to be at the bottom of the soil layer in the hot summer time without antecedent rain. Description of scenarios (abcd) is shown in Table 4.

\subsection{Landslide Susceptibility Assessment}

The distributions of factor of safety in the Cau river basin are illustrated in Fig. 8. With regard to the rainstorm event in 2013, case 1 in the soil depth estimation (0031) produced lower values of the factor of safety than the outputs from the soil-depth case 2 . scenarios $(0002,0012,0022,0032)$. Under the same condition of soil depth $(d=2)$, when the entire basin was covered by bare soil (0002), the northwest and southeast basin obtained more unstable area when compared to the Fs results from options 0012, 0022, and 0032. When the same database of land-use was utilized, i.e. JAXA, changes in the land surface cover

Table 1 Rain amount regarding the historical rainfall event, the 24-hour PMP and the 48-hour PMP (mm).

\begin{tabular}{|c|c|c|c|c|c|c|}
\hline \multirow{2}{*}{ Station } & & \multicolumn{2}{|c|}{ Location } & \multirow{2}{*}{ Rainstorm in 2013} & \multirow{2}{*}{ 24-hour PMP } & \multirow{2}{*}{ 48-hour PMP } \\
\hline & & Latitude & Longitude & & & \\
\hline Bac Kan & BK & 22.15 & 105.833 & 186.3 & 482.1 & 651.3 \\
\hline Cho Don & $\mathrm{CD}$ & 22.15 & 105.583 & 178.2 & 493.8 & 572.8 \\
\hline Phu Thong & PT & 22.27 & 105.883 & 294.0 & 420.9 & 524.7 \\
\hline Dinh Hoa & DH & 21.92 & 105.633 & 189.0 & 468.9 & 552.9 \\
\hline Dai Tu & DT & 21.63 & 105.633 & 164.7 & 497.1 & 542.9 \\
\hline Thai Nguyen & $\mathrm{TN}$ & 21.60 & 105.533 & 222.2 & 499.0 & 520.7 \\
\hline Pho Yen & PY & 21.43 & 105.883 & 200.7 & 496.2 & 529.3 \\
\hline Vo Nhai & VN & 21.70 & 105.933 & 250.0 & 492.4 & 530.7 \\
\hline
\end{tabular}


Table 2 Average values of soil properties in Cau basin.

\begin{tabular}{llll}
\hline Parameter & & Unit & Range of value \\
\hline$c_{s}$ & Soil cohesion & $\mathrm{kN} / \mathrm{m}^{2}$ & $14.7-29.0$ \\
$\varphi$ & Soil internal friction angle & $\mathrm{o}$ & $18.0-26.8$ \\
$\gamma_{s}$ & Unit weight of soil & $\mathrm{kN} / \mathrm{m}^{3}$ & $20.6-26.6$ \\
$K_{s}$ & Hydraulic conductivity & $\mathrm{m} / \mathrm{s}$ & $5.06 \times 10^{-6}-4.70 \times 10^{-5}$ \\
\hline
\end{tabular}

Table 3 Summary of two cases in the soil depth determination.

\begin{tabular}{lllc}
\hline \multirow{2}{*}{ Group } & Lithology & \multicolumn{2}{c}{ Range of soil depth $(\mathrm{m})$} \\
\cline { 3 - 4 } 1 & Quaternary deposits & Case 1 & Case 2 \\
2 & Sedimentary aluminosilicate rocks and sedimentary quartz rocks & $1.0-3.5$ & $1.5-3.0$ \\
3 & Sedimentary carbonate rocks & $0.5-3.5$ & $1.3-3.0$ \\
4 & Mafic-ultramafic magma rocks & $1.5-4.0$ & 1.3 .0 \\
5 & Acid-neutral magmatic rocks & $1.0-4.0$ & $1.5-3.0$ \\
6 & Metamorphic rocks with rich aluminosilicate components & $0.5-4.0$ & $0.5-3.0$ \\
7 & Metamorphic rocks with rich quartz components & $1.0-4.0$ & $1.0-3.0$ \\
\hline
\end{tabular}

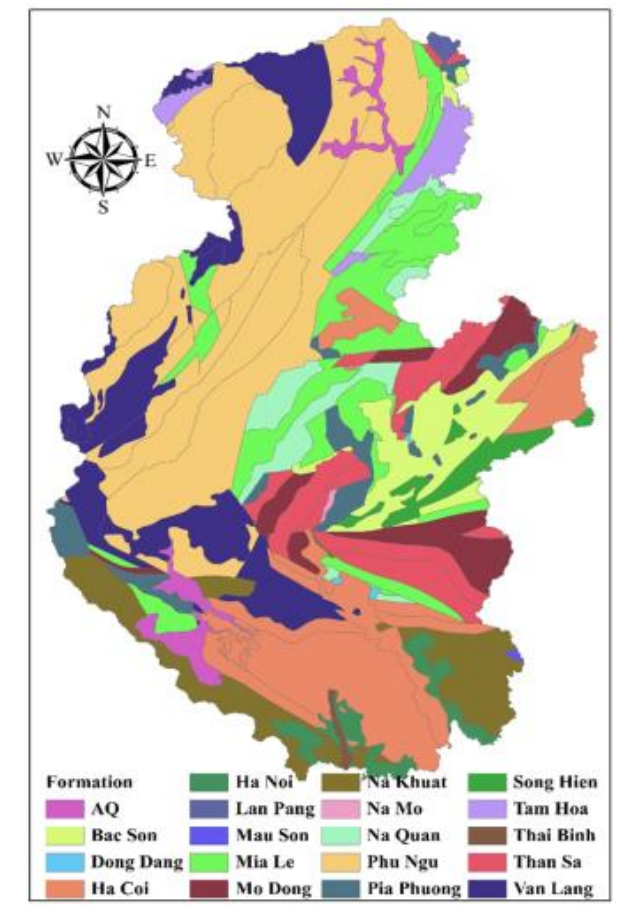

(a) Soil depth case 1

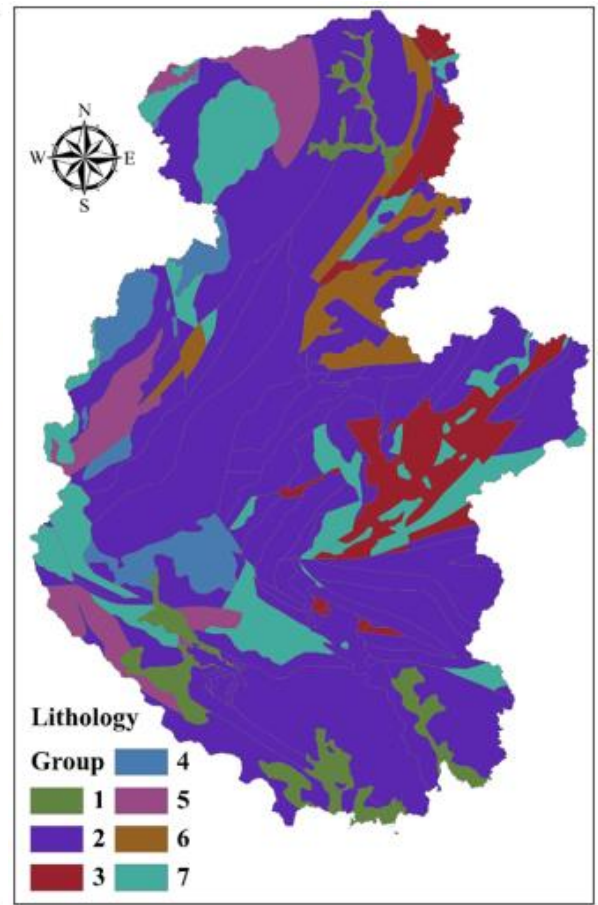

(b) Soil depth case 2

Fig. 7 Soil depth determination map in Cau Basin.

Table 4 Summary of scenario (a-d).

\begin{tabular}{lllll}
\hline \multirow{2}{*}{ Option } & Rainfall event & Rain distribution & Land cover & Soil depth \\
\cline { 2 - 5 } & $\mathrm{a}$ & $\mathrm{b}$ & $\mathrm{c}$ & $\mathrm{d}$ \\
\hline 0 & Historical event & Actual distribution & Bared soil & Case 1 \\
1 & 24-hour PMP & Type 1 & USGS 2010 & Case 2 \\
2 & 48-hour PMP & Type 2 & JAXA 2007 & \\
3 & & Type 3 & JAXA 2015 & \\
\hline
\end{tabular}




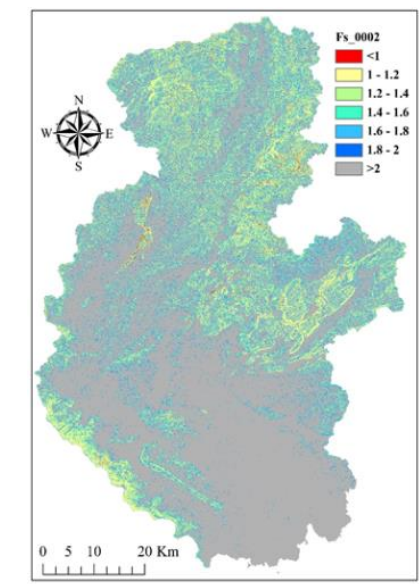

a)

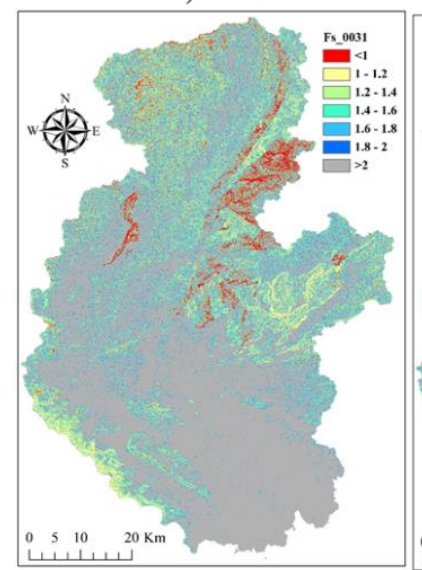

e)

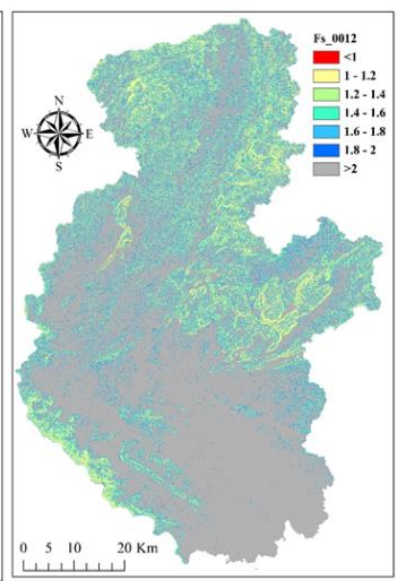

b)

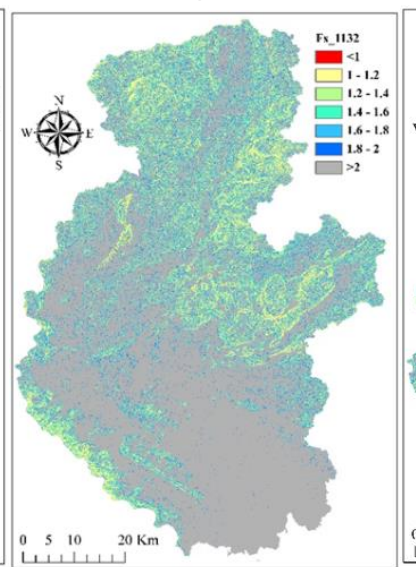

f)

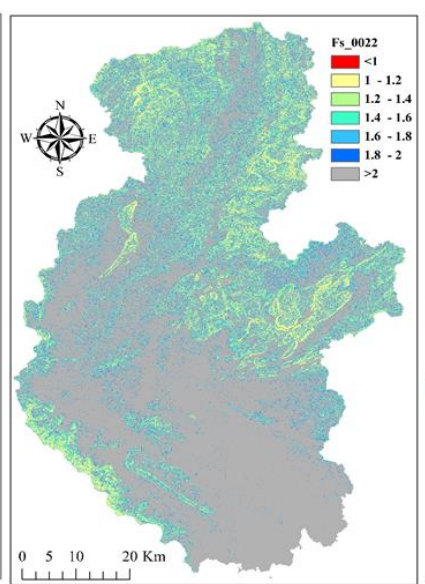

c)

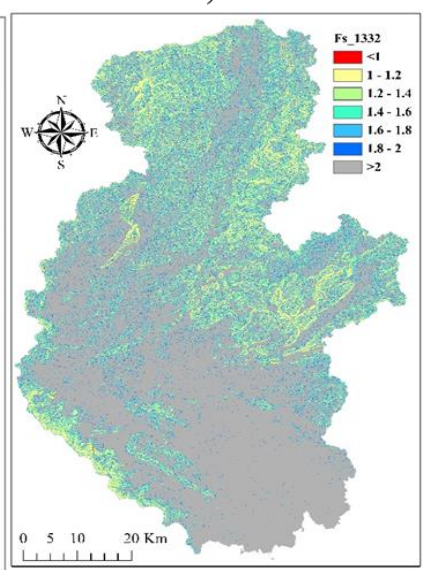

g)

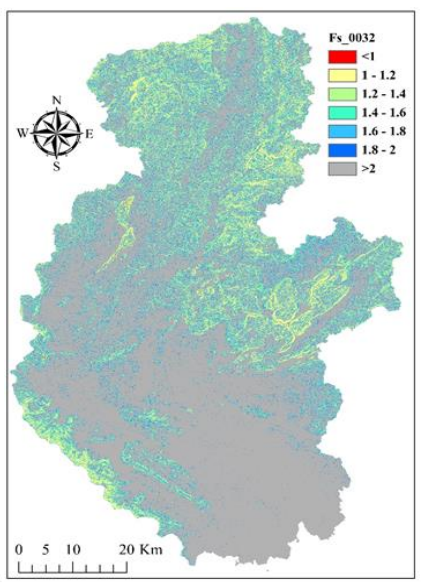

d)

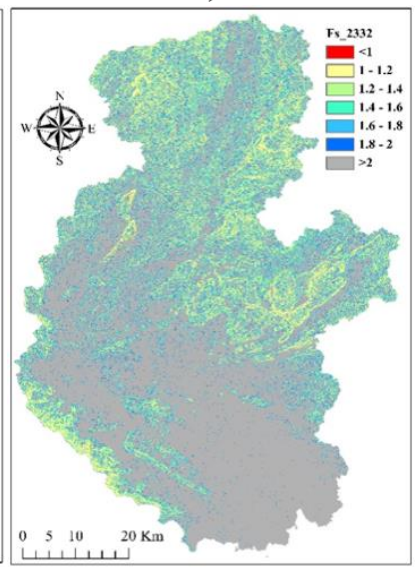

h)

\begin{tabular}{llllllllll}
\hline \multirow{2}{*}{ Scenario description } & & \multicolumn{7}{c}{ Fig. name of scenario (abcd) } \\
\cline { 2 - 9 } & & a) 0002 & b) 0012 & c) 0022 & d) 0032 & e) 0031 & f) 1132 & g) 1332 & h) 2332 \\
\hline Rainfall event & a & 0 & 0 & 0 & 0 & 0 & 1 & 1 & 2 \\
Rain distribution & b & 0 & 0 & 0 & 0 & 0 & 1 & 3 & 3 \\
Land cover & c & 0 & 1 & 2 & 3 & 3 & 3 & 3 & 3 \\
Soil depth & d & 2 & 2 & 2 & 2 & 1 & 2 & 2 & 2 \\
\hline
\end{tabular}

Fig. 8 The factor of safety (Fs) regarding scenarios map.

from 2007 (0022) to 2015 (0032) resulted in changes in the value of factor of safety in many parts in the basin (Fig. 9b) illustrates the differences of the factor of safety between option 0032 and 0012; the result indicated that the differences between the two databases of land cover including JAXA performed significant impact on the model simulation.

In order to test the behavior of the model simulation at actual location of sliding, we analyzed the landslide data in 2013 from the Government project and the data from the field investigation in September 2017 and September 2018. Because it was difficult to obtain the shape and area of each sliding point, the evaluation of slope stability was implement on a basis of a square size 30 meter $\times 30$ meter at 141 landslide points recorded in 2013 and 57 landfall points investigated in 2017-2018. As described in Figs. 10 and 11, about 80 percent of the sliding area had the value of Fs less than 2.0. The two databases of landslide showed similar behavior in the distribution of the factor of safety. The case 1 in the soil depth determination still had the highest score of area having low factor of safety; the bared soil cover (0002) also displayed at the upper boundary among the four options using the same 


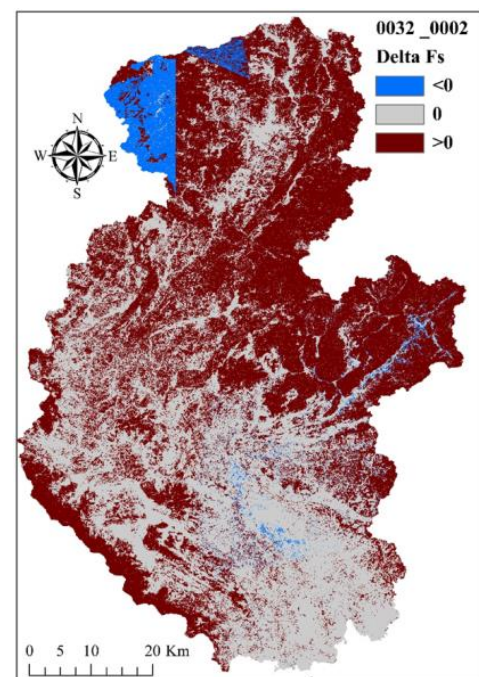

a)

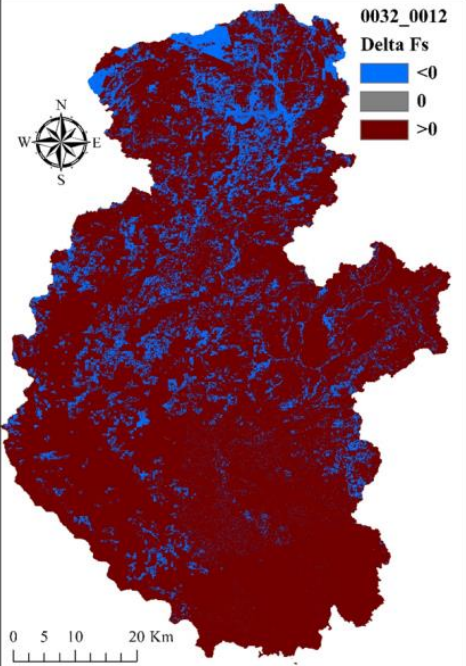

b)

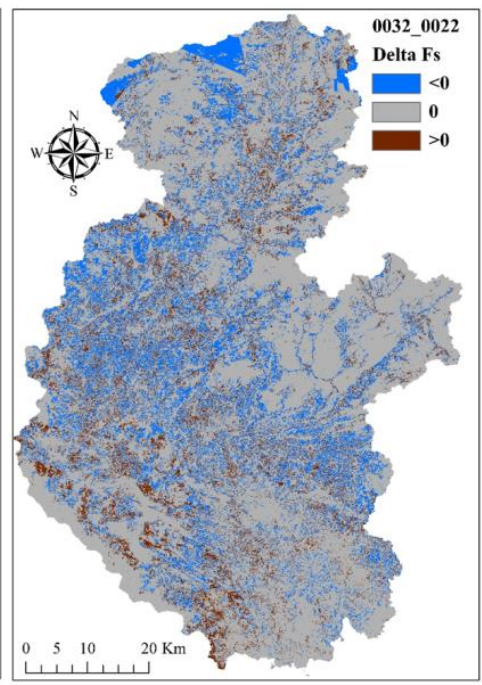

c)

(a) Fs_0032 and Fs_0002

(b) Fs_0032 and Fs_0012

(c) Fs_0032 and Fs_0022

Fig. 9 Difference of the factor of safety (Delta Fs) map on scenario.

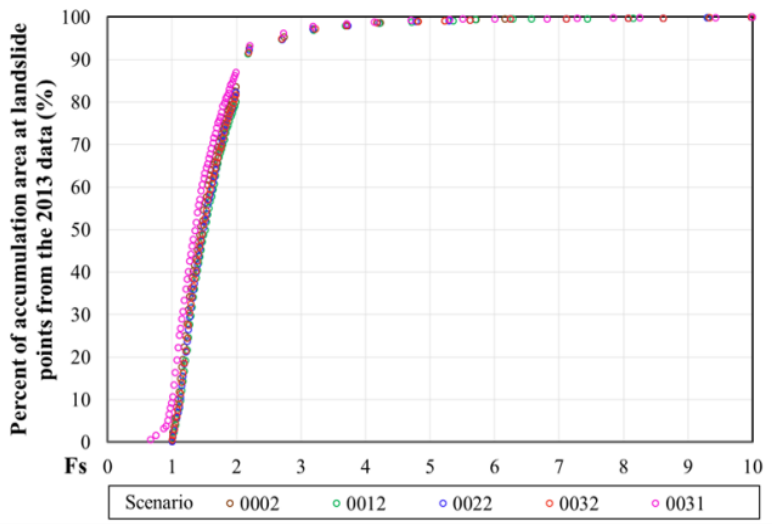

a)

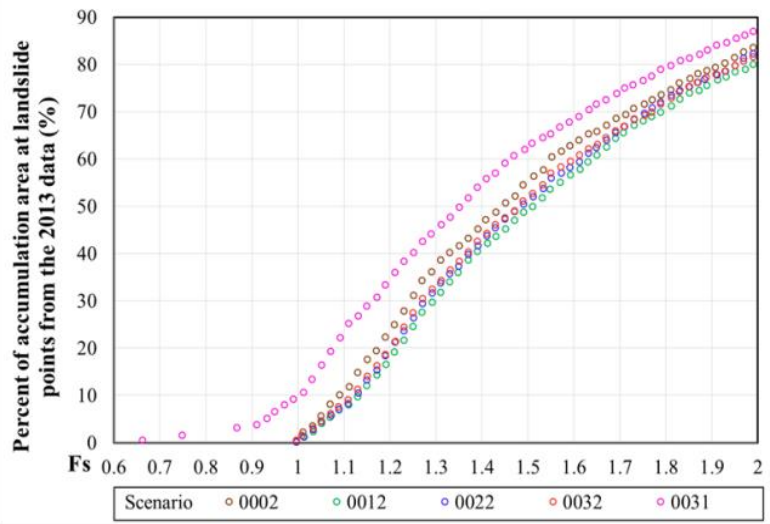

b)

Fig. 10 Relationship between distribution of the factor of safety (Fs) and percent of accumulation area. a) Fs in accordance with percent of accumulation area at landslide points from the 2013 data. b) Detail of Fig. 10a) regarding the Fs below 2.0 .

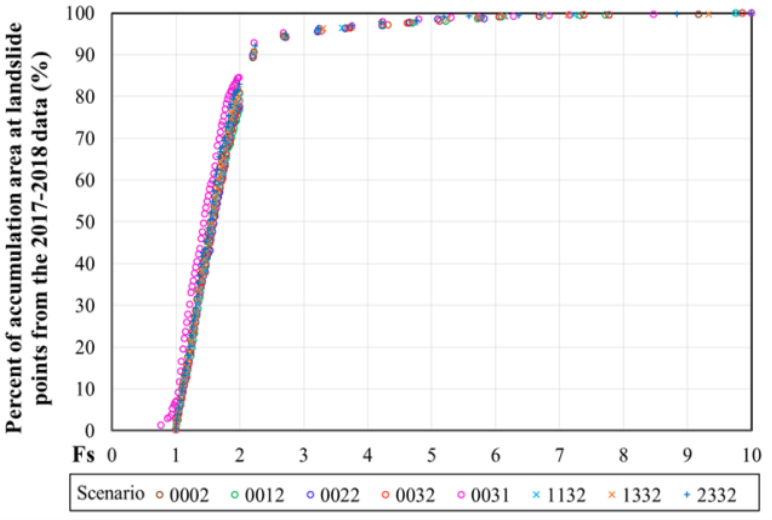

a)

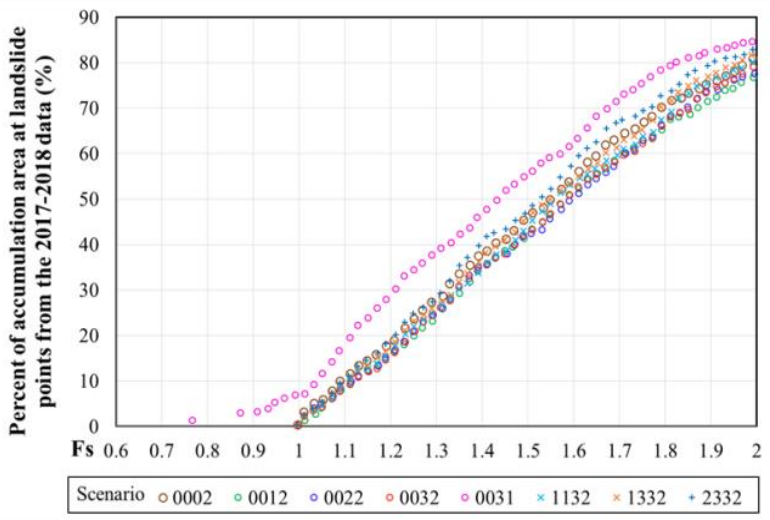

b)

Fig. 11 Relationship between Distribution of the factor of safety (Fs) and percent of accumulation area. a) Fs in accordance with percent of accumulation area at landslide points from the 2017-2018 data. b) Detail of Fig. 11a) regarding the Fs below 2.0. 
condition of soil depth. In addition, in case the rainfall changed to the proposed extreme event of 24-hour PMP (1332) and 48-hour PMP (2332), the proportion of cell area that could be prone to the slope failure was higher than output from scenarios using actual rain-event (0032) (Figs. 11a and b).

\section{Discussion and Conclusions}

The scenarios showed that the proportion of area having the Fs below 1.5 was about $48-63 \%$ and $43-54 \%$ of the total tested area regarding the landslide data in 2013, and 2017-2018 respectively. According to the classification of [23], the stability condition was grouped in four classes including (i) Unstable in case Fs $<1$, the stability requires stabilizing factors; (ii) Quasi-stable in case $1 \leq \mathrm{Fs}<1.25$, the instability would be resulted from minor destabilizing factors; (iii) Moderately stable in case $1.25 \leq \mathrm{Fs}<1.5$, the instability would be resulted from moderate destabilizing factors; and (iv) Stable in case Fs $\geq 1.5$, the instability would be resulted from major destabilizing factors. It is noted that it was too difficult to evaluate slope failure records at remote area; most of the historical sliding points in this study were recorded along the main arteries and often associated with the man-made slopes. Comparing to the case of natural slope condition, the instability of those artificial slopes was more prone to changes in the environmental conditions. The simulation hence proved the agreement with the slope-failure hazards when the destabilizing factors such as slope cut for construction were added. The results also illustrate the sensitivities of TRIGRS to the DEM input especially when the natural slope condition was changed. In addition, under the same rainfall event, differences in the storm distribution also led to the changes in the landslide prone region; for example, the storm distribution type 3 (1332) would produce more instability area than the simulation using the storm distribution type 1 (1132). The increase in rainfall amount and storm duration would result in the rise of the instability area (scenarios 1332 and 2332).
There are certain uncertainties raising from the soil properties and soil depth determination, assumption of groundwater, as well as the same root cohesion for all tree cover in the forest-related region. However, the application of TRIGRS model in a regional scale would provide important references for the distribution of landslide prone area regarding scenarios about changes of weather condition and land cover situation. It thus would support local authorities in obtaining more adequate land planning strategies in a river basin to mitigate potential hazard from the slope failure issue.

\section{Acknowledgments}

This research was supported by the Vietnamese Government scholarship (project 911); and the Social Implementation Program on Climate Change Adaptation Technology (SI-CAT) of MEXT, Japan.

\section{References}

[1] To, N. T., and KATO, T. 2018. "Characteristics and Development of Policy and Institutional Structures of Emergency Response in Vietnam.” International Journal of Disaster Risk Reduction 31: 729-41.

[2] Broxton, P. D., Zeng, X., Sulla-Menashe, D., and Troch, P. A. 2014. "A Global Land Cover Climatology Using MODIS Data.” J. Appl. Meteorol. Climatol. 53: 1593-605. https://doi.org/10.1175/JAMC-D-13-0270.1.

[3] Dieu, T. B., Owe, L., Inge, R., and Dick, O. 2011. "Landslide Susceptibility Analysis in the Hoa Binh Province of Vietnam Using Statistical Index and Logistic Regression." Nat. Hazards 59: 1413-44.

[4] Metternicht, G., Hurni, L., and Gogu, R. 2005. "Remote Sensing of Landslides: An Analysis of the Potential Contribution to Geo-Spatial Systems for Hazard Assessment in Mountainous Environments." Remote Sens. Environ. 98: 284-303. https://doi.org/10.1016/j.rse.2005.08.004.

[5] Westen, C. J., van Rengers, N., Terlien, M. T. J., and Soeters, R. 1997. "Prediction of the Occurrence of Slope Instability Phenomenal through GIS-Based Hazard Zonation." Geol. Rundschau 86: 404-14. https://doi.org/10.1007/s005310050149.

[6] JAXA. 2016. "High-Resolution Land Use and Land Cover Map of Northern Region of Vietnam (Released in Sep.2016/Version 16.09)." Adv. L. Obs. Satell., ALOS Res. Appl. Proj. EORC, JAXA. 
[7] Baum, R. L., Savage, W. Z., and Godt, J. W. 2008. "TRIGRS-A Fortran Program for Transient Rainfall Infiltration and Grid-Based Regional Slope-Stability Analysis, Version 2.0." U.S. Geol. Surv. Open-File Rep. 75: 1159. https://doi.org/Open-File Report.

[8] Baum, R. L., Godt, J. W., and Savage, W. Z. 2010. "Erratum: Estimating the Timing and Location of Shallow Rainfall-Induced Landslides Using a Model for Transient, Unsaturated Infiltration.” J. Geophys. Res. 115: 1-26. https://doi.org/doi:10.1029/2009JF001321.

[9] Saulnier, G.-M., Beven, K., and Obled, C. 1997. "Including Spatially Variable Soil Depth in TOPMODEL." J. Hydrol. 202: 158-72.

[10] Pollen-Bankhead, N., and Simon, A. 2009. "Enhanced Application of Root-Reinforcement Algorithms for Bank-Stability Modeling." Earth Surf. Process. Landforms 34: 471-80. https://doi.org/10.1002/esp.1690.

[11] WMO. 2009. "Manual on Estimation of Probable Maximum Precipitation (PMP)." World Meteorological Organization.

[12] Le, T. T. T., Kawagoe, S., and Sarukkalige, R. 2018. "Estimation of Probable Maximum Precipitation at Three Provinces in Northeast Vietnam Using Historical Data and Future Climate Change Scenarios." J. Hydrol. Reg. Stud. Revised.

[13] Duc, D. M. 2009. "Heavy Rainfall Induced Landslides in Bac Kan and Binh Dinh Provinces." VNU J. Sci. earth Sci. 25: 1-9.

[14] Duc, D. M. 2004. "Numerical Simulation for Slope Stability Analysis and Landslide Prediction in Bac Kan Province, Northeast Vietnam.” Int. Symp. Geoinformatics Spat. Infrastruct. Dev. Earth allied Sci.

[15] Duc, D. M., Duc, D. M., AND Ngoc, D. M. 2018. "Effects of Residual Soil Characteristics on Rainfall-Induced Shallow Landslides v in Bac Kan Province, Vietnam."
Advances and Applications in Geospatial Technology and Earth Resources GTER 2017 Springer, Cham. https://doi.org/https://doi.org/10.1007/978-3-319-68240-2 _.13.

[16] Duc, D. M., and Khang, D. Q. 2011. "Interpretation of Landslide Danger at Deo Gio (Wind Pass) Area Ngan Son District, Bac Kan Province." Vietnam Geotech. J. 15: 10-9.

[17] Duc, D. M., Khang, D. Q., Binh, N. V., Loi, V. V., Sinh, P. T., Duc, P. H., and Truc, N. N. 2012. "Mechanism of Sinkhole Formation in Underground Limestone Karstic Areas (A Case Study of Na Tum Area, Bac Kan Province)." J. Min. earth Sci. 38: 16-24.

[18] Hue, T. T. 2004. "Research on Crack and Subsidence Hazards in Mountainous Region in North Vietnam." Vietnam Geogr. Acad.

[19] Son, D. T. 2011. "Study on Potential Infiltration and Water Retention Ability in Forest Land in Dinh Hoa, Thai Nguyen." Thai Nguyen University.

[20] Docker, B. B., and Hubble, T. C. T. 2008. "Quantifying Root-Reinforcement of River Bank Soils by Four Australian Tree Species." Geomorphology 100: 401-18. https://doi.org/10.1016/j.geomorph.2008.01.009.

[21] Kuriakose, S. L. 2010. "Physically-Based Dynamic Modelling of the Effect of Land Use Changes on Shallow Landslide Initiation in the Western Ghats of Kerala, India." University of Twente.

[22] Coder, K. D. 2014. "Tree Anchorage \& Root strength." Univ. Georg. Warn. Sch. For. Nat. Resour. Monogr. Publ. WSFNR 14: 67.

[23] Tran, T. V., Lee, G., An, H., and Kim, M. 2017. "Comparing the Performance of TRIGRS and TiVaSS in Spatial and Temporal Prediction of Rainfall-Induced Shallow Landslides." Environ. Earth Sci. 76 (8): 1-16. https://doi.org/10. 1007/s12665-017-6635-4. 